\title{
KETAHANAN MATERIAL BAJA SELIMUT FIBERGLASS PADA KONSTRUKSI BANGUNAN PANTAI
}

\author{
Rakhmawati Natsir' ${ }^{1)}$, Budiawan Sulaeman ${ }^{2)}$ \\ ${ }^{1)}$ Dosen Program Studi Teknik Sipil, Universitas Andi Djemma, Palopo \\ ${ }^{2)}$ Dosen Program Studi Teknik Informatika, Universitas Andi Djemma, Palopo \\ ${ }^{1)}$ wathi07@gmail.com \\ ${ }^{2)}$ budiawan.unanda@yahoo.com
}

\begin{abstract}
Abstrak
Besi yang mengalami korosi membentuk karat $\mathrm{Fe} 2 \mathrm{O} 3$ x H2O. Korosi atau proses pengaratan merupakan proses elektron kimia. Pada proses pengaratan, besi $(\mathrm{Fe})$ bertindak sebagai pereduksi dan oksigen $(\mathrm{O} 2)$ yang terlarut dalam air bertindak sebagai pengoksidasi. Persamaan reaksi pembentukan karat sebagai berikut; Anode: $\mathrm{Fe}(\mathrm{s}) \rightarrow \mathrm{Fe} 2+(\mathrm{aq})$ ) $2 \mathrm{e}$ dan Katode: $\mathrm{O} 2(\mathrm{~g})+4 \mathrm{H}+(\mathrm{aq})+4 \mathrm{e}-\rightarrow 2 \mathrm{H} 2 \mathrm{O}(\mathrm{l})$. Karat yang terbentuk pada logam akan mempercepat proses pengaratan berikutnya. Fiberglass disamping sifatnya yang ringan, kuat dan memadat setelah diproses kimiawi dengan bahan dasar resin dan katalis, sifatnya yang mengikat dapat mengikat bahan lain dengan kuat. Pada pengujian regangan terjadi perubahan yang signifikan hal ini dipengaruhi, adanya material baru yang masuk kedalam bahan uji sehingga regangan material tersebut regangannya berubah dari waktu kewaktu. Pada pengujian Modulus Elastis terjadi perubahan yang signifikan (bertambah besar niali rata - ratanya) berarti bahan uji semakin sulit untuk direntangkan dalam artian membutuhkan gaya yang lebih besar. Hal ini di pengaruhi karena fiberglass mengikat material dengan kuat sehingga material bertambah sulit untuk direntangkan. Dari hasil uji diatas dapat dilihat dalam perendaman selama satu bulan uji tarik uji tarik meningkat dan masuk pada bulan kedua dan ketiga pengujian kuat tarik menurun, diakibatkan terjadinya korosi pada material.
\end{abstract}

Kata Kunci: baja selimut fiberglass, korosi.

\section{PENDAHULUAN}

Perkembangan ilmu pengetahuan dan kemajuan teknologi seiring sejalan dengan perkembangan peradaban manusia. Ilmu sains yang didalamnya terangkum teknologi adalah kelompok ilmu pengetahuan yang banyak memberikan sumbangan pemikiran dalam perkembangan peradaban manusia. Produk teknologi memberikan kemudahan berupa alat guna mengembangkan teori-teori dalam sains. Ilmu fisika dan ilmu kimia sebagai bagian dari ilmu sains yang mempelajari tentang materi atau zat yang meliputi sifat fisis, komposisi, perubahan dan energi yang dihasilkannya. Oleh karena itu, perkembangan ilmu pengetahuan dan teknologi yang sangat pesat saat ini tidak terlepas dari ilmu fisika dan ilmu kimia sebagai salah satu ilmu dasar yang dikembangkan kedalam satu ilmu terapan yakni ilmu mekanika dan ilmu bahan. Selain itu, konsep-konsep fisika dan kimia akan membantu kita dalam memahami ilmu lainnya, seperti ilmu teknik sipil, ilmu kesehatan, teknologi industri, teknologi informasi, teknologi manufaktur dan lain - lain.

Karena sumbangsinya dalam perkembangan teknologi saat ini cukup banyak tidak terkecuali pada pembangunan gedung-gedung, menara, jembatan, dan lain sebagainya, yang mana perlu kita pahami bahwasannya pembangunan tersebut memanfaatkan konsep-konsep dasar fisika khususnya kekuatan bahan dan konsep dasar kimia yang membahas tentang kerusakan material.

Fiberglass disamping sifatnya yang ringan, kuat dan memadat setelah diproses kimiawi dengan bahan dasar resin dan katalis, fiberglass mempunyai sifat lain di antaranya sifat aslinya berbentuk cair, sehingga dapat menjangkau sisi dalam dari material yang akan diselimuti selama proses kimiawi berlangsung, sifatnya yang mengikat dapat mengikat bahan lain dengan kuat selama bahan itu tidak mengandung 
air dan setelah proses kimiawi berlangsung fiberglass dapat memadat serta dapat dibuat mengkilap seperti kaca dengan proses lebih lanjut. (Kleinschmidt, 2000)

Berdasarkan fanomena di atas, penulis mencoba menguji material baja yang diselumuti fiberglass. Hal ini dilakukan untuk menekan pertumbahan korosi pada konstruksi bangunan yang terdapat di pinggiran pantai, mempertimbangkan gaya tarik dan gaya tekan yang terjadi pada konstruksi dengan melakukan korosivitas sebelum material diujikan. Karena dirasa penting untuk pengembangan ilmu pengetahuan mekanika maupun ilmu bahan untuk mengetahui kekuatan sebuah kontruksi dan dapat memperpanjang umur kontruksi, maka dilakukan sebuah penelitian untuk mengetahui kekuatan material baja yang diselimuti oleh fiberglass.

Berdasarkan latar belakang di atas, adapun rumusan masalah penelitian ini adalah (1)Menganalisis tingkat korosivitas material baja selimut fiberglass pada bangunan pantai. (2)Menganalisis kekuatan tarik dan kekuatan tekan material baja selimut fiberglass pada bangunan pantai. Dengan menggunakan skala laboratorium yang mengacuh pada standarisasi SNI No. 07- 2529 - 1991 Uji Tarik Baja Dewan Standarisasi Indonesia. Untuk mengetahui ketahanan material dengan perlakuan merendam material kedalam air asin. Hasilnya dapat dijadikan acuan dalam menentukan kualitas terbaik material.

\section{Baja}

Baja ST 37 merupakan baja karbon rendah yang mempunyai kandungan karbon kurang dari 0,3\% dan lebih dari 99\% seperti pada tabel berikut;

Tabel 1.Komposisi Baja Karbon rendah tipe ST 37 (Novizal \& Eva Rediawati 2012)

\begin{tabular}{cccc}
\hline Unsur & Kandungan $(\%)$ & Unsur & Kandungan (\%) \\
\hline $\mathrm{Fe}$ & 99,310 & $\mathrm{~S}$ & 0,015 \\
\hline $\mathrm{Mn}$ & 0,375 & $\mathrm{Co}$ & 0,007 \\
\hline $\mathrm{C}$ & 0,118 & $\mathrm{Nb}$ & 0,006 \\
\hline $\mathrm{Si}$ & 0,055 & $\mathrm{Cu}$ & Max. 0,004 \\
\hline $\mathrm{W}$ & 0,046 & $\mathrm{Mo}$ & Max. 0,005 \\
\hline $\mathrm{Ni}$ & 0,026 & $\mathrm{Cl}$ & Max. 0,002 \\
\hline $\mathrm{Cr}$ & 0,021 & $\mathrm{~V}$ & Max. 0,001 \\
\hline $\mathrm{P}$ & 0,017 & - & - \\
\hline
\end{tabular}

Baja adalah logam paduan, logam besi sebagai unsur dasar dengan beberapa elemen lainnya, termasuk karbon. Kandungan unsur karbon dalam baja berkisar antara $0.2 \%$ hingga $2.1 \%$ berat sesuai grade-nya. Elemen ini selalu ada dalam baja yaitu karbon, mangan, fosfor, sulfur, silikon, dan sebagian kecil oksigen, nitrogen dan aluminium.

Selain itu, ada elemen lain yang ditambahkan untuk membedakan karakteristik antara beberapa jenis baja diantaranya: mangan, nikel, krom, molyb denum, boron, titanium, vanadium dan niobium. Dengan memvariasikan kandungan karbon dan unsur paduan lainnya, berbagai jenis kualitas baja bisa didapatkan. Fungsi karbon dalam baja adalah sebagai unsur pengeras dengan mencegah dislokasi bergeser pada kisi kristal (crystal lattice) atom besi. Baja karbon ini dikenal sebagai baja hitam karena berwarna hitam, banyak digunakan untuk peralatan pertanian. Penambahan kandungan karbon pada baja dapat meningkatkan kekerasan (hardness) dan kekuatan tariknya (tensile strength), namun di sisi lain membuatnya menjadi getas (brittle) serta menurunkan keuletannya (ductility). 
Meskipun baja sebelumnya telah diproduksi oleh pandai besi selama ribuan tahun, penggunaannya menjadi semakin bertambah ketika metode produksi yang lebih efisien ditemukan pada abad ke-17. Dengan penemuan proses Bessemer di pertengahan abad ke-19, baja menjadi material produksi massal yang membuat harga produksinya menjadi lebih murah. Saat ini, baja merupakan salah satu material paling umum di dunia, dengan produksi lebih dari 1,3 miliar ton tiap tahunnya. Baja merupakan komponen utama pada bangunan, infrastruktur, kapal, mobil, mesin, perkakas, dan senjata. Baja modern secara umum diklasifikasikan berdasarkan kualitasnya oleh beberapa lembaga-lembaga standar. (Tata Surdia, 2000).

\section{Fiberglass}

Pada Era globalisasi seperti sekarang ini perkembangan telah memberikan sumbangsi dan peluang teciptanya suatu produk Fiberglass dimana penggunaan bahan sebagai bahan baku pembuatan kapal atau boat serta meramba kepada kerajianan tangan dan berbagai produk misalnya galon air, westafel, bacttab, hasil produksi/ bidang panjat dinding, dasboard mobil dan lain - lain.

Fiberglass untuk pembuatan produk pada dasarnya campuran bahan-bahan yang terdiri dari, Campuran cairan resin (water glass), Katalis dan Mett/ Roving serat fiber, proses pembuatannya semua bahan tadi dicampur, sehingga akan bereaksi dari bahan berbentuk cair berubah menjadi padat. Bahan-bahan ini mudah didapatkan dipasaran dan tergolong murah, dimana dari bahan-bahan tersebut di atas dapat diuraikan sebagai berikut : resin, katalis dan serat kaca.

\section{Pengujian Material}

digunakan analisis data secara statistik, yaitu analisis data dengan menggambarkan kualitas material secara umum yang disajikan dalam bentuk tabel maupun grafik sesuai dengan SNI No. 07- 2529 - 1991 Uji Tarik. Sebelum material diuji dalam skala laboratorium benda uji mengalami perlakuan korosivitas (lihat tabel 7 jadwal pelaksanaan penelitian).

\section{METODOLOGI PENELITIAN Waktu dan Lokasi}

Penelitian akan diadakan didua tempat, pembuatan material/ bahan uji dilakukan di Laboratorium Teknik Sipil Unversitas Andi Djemma Kota Palopo dengan alasan tempat tinggal peneliti berada di Kota Palopo. Pengujian material/ Bahan Uji dilakukan di laboratorium Uji Material Akademi Teknik Industri Makassar, karena belum ada alat pengujian material/ laboratorium material di Kota Palopo. Dalam penelitian ini membutuhkan waktu selama \pm 5 bulan. Mulai Bulan Juni sampai dengan Bulan Oktober 2018.

Tabel 2. Alat dan Bahan yang digunakan

\begin{tabular}{lll}
\hline \multirow{2}{*}{ No. } & \multicolumn{1}{c}{ Bahan } & \multicolumn{1}{c}{ Jenis } \\
\cline { 2 - 3 } & \multicolumn{1}{c}{ alat } \\
b. Kesin & a. Peralatan Gambar \\
c. Serat Fiber & b. Sarung Tangan + Masker \\
d. Baja Karbon ST $37 \varnothing 10$ & c. Gelas Ukur \& Wadah Adonan \\
& mm & d. Gunting \& Kuas 1" \\
& & e. Mesin Potong \& Gerinda \\
& f. Gergaji tangan \\
& g. Kikir dan amplas gosok \\
& h. Aneka Alat ukur \\
\hline
\end{tabular}




\begin{tabular}{lll}
\hline \multirow{2}{*}{ No. } & \multicolumn{1}{c}{ Jenis } \\
\hline & Bahan & \multicolumn{1}{c}{ Alat } \\
& i. Mesin Bubut \\
& j. Mesin Uji Tarik \\
\hline
\end{tabular}

Dalam penelitian ini, ditetapkan ketebalan fiberglass $\pm 0,050 \mathrm{~cm}$. Setiap polesan fiberglass dengan menggunakan kuas, sekali oles ketebalan mencapai 0,020 - 0,025 $\mathrm{cm}$.

\section{Peubah yang diamati}

1. Tingkat korosivitas, Material dalam pengujian material akan diamati selama 3 bulan, untuk mengetahui tingkat korosivitas material, material akan di rendam kedalam air asin selama waktu yang dibutuhkan, kemudian ditimbang untuk mengetahui perubahan berat jenis material.

2. Uji Material Skala Laboratorium, Kekutan Tarik menggunakan material baja ST 37. Perlakuan uji mengacuh pada Standar Nasional Indonesia SNI No. 07- 2529 1991 Uji Tarik Baja.

\section{Rancangan Penelitian}

Penelitian akan dilaksanakan dalam bentuk eksperimen yang terdiri dari dua perlakukan dan satu kontrol. Pelakuan A adalah baja yang tidak diselubungi dengan fiberglass sebagai kontrol, Perlakuan B adalah baja yang diselubungi dengan fiberglass setebal $\pm 0,050 \mathrm{~cm}$. Pembuatan Bahan Uji Tarik sebagai berikut;

1. Membuat gambar kerja bahan uji yang akan dibuat dengan dimensi ukuran Diameter 0,10 dan Panjang 11,4.

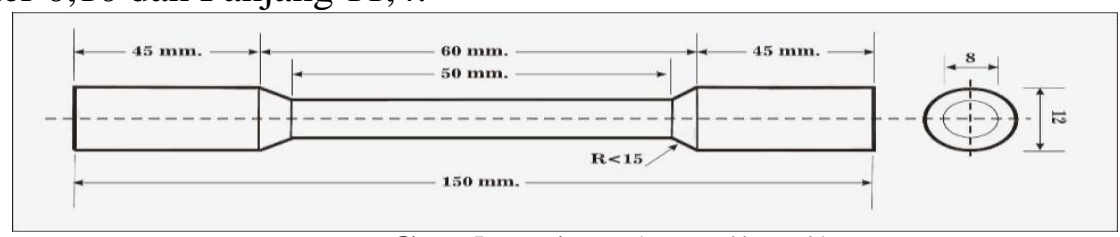

Gambar 1. Bahan uji tarik

2. Potong material sesuai ukuran, sebanyak 12 buah

3. Lakukan proses pembubutan pada bagian yang akan diuji (lihat gambar 1)

4. Haluskan permukaan dengan menggunakan amplas gosok dan mengikir sudut sudut untuk menghilangkan sisa bahan akibat kerja mesin bubut.

5. Bahan uji 9 buah akan diselimuti dengan menggunakan fiberglass setetebal \pm $0,050 \mathrm{~cm}$ dan sisanya tidak diberi perlakuan.

Desain rancangan ini adalah acak lengkap dengan tiga ulangan.

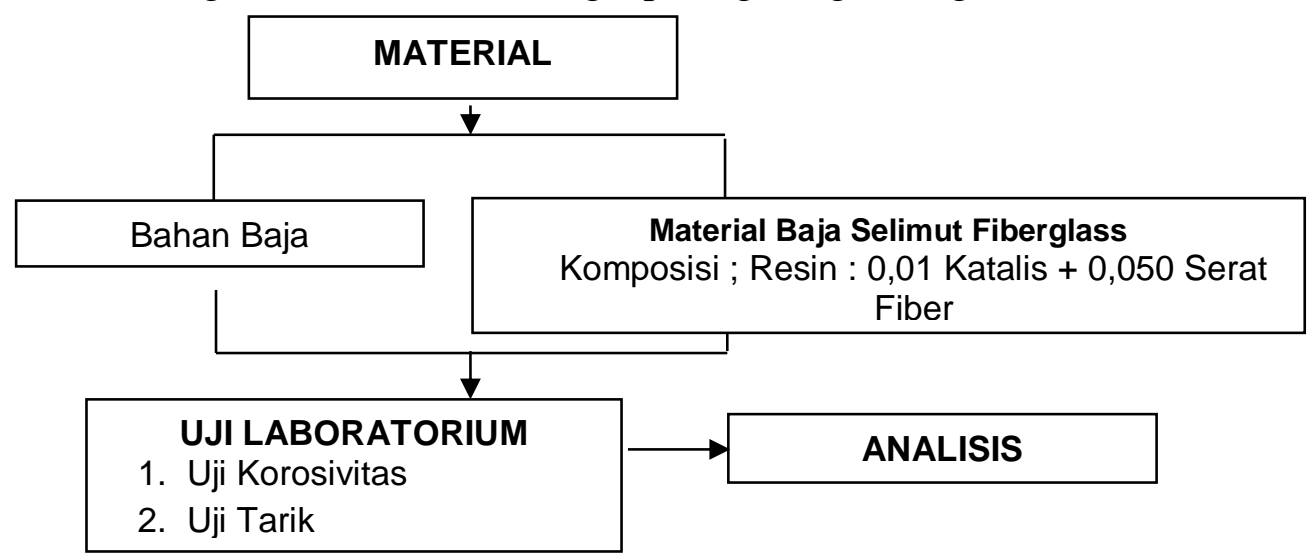

Gambar 2. Diagram Blok Pengujian Material 


\section{Pengumpulan dan Analisis Data}

Pengujian material dilakukan dengan cara material di rendam diadalam wadah dengan menggunakan air laut. Perlakuan ini dilakukan dengan mengasumsikan lingkungan yang berada pada konstruksi bangunan pantai.

Setiap periode berbeda masing-masing satu bulan, dua bulan, dan tiga bulan. Dilakukan pengujian material untuk melihat ketahanan material baja selimut fiberglass dengan pengujian material di laboratorium mengacu pada ketentuan Standar Nasional Indonesia (SNI).

\section{HASIL DAN PEMBAHASAN}

Pembuatan Material Uji

Bubut material tersebut sesuai gambar yang telah direncanakan.

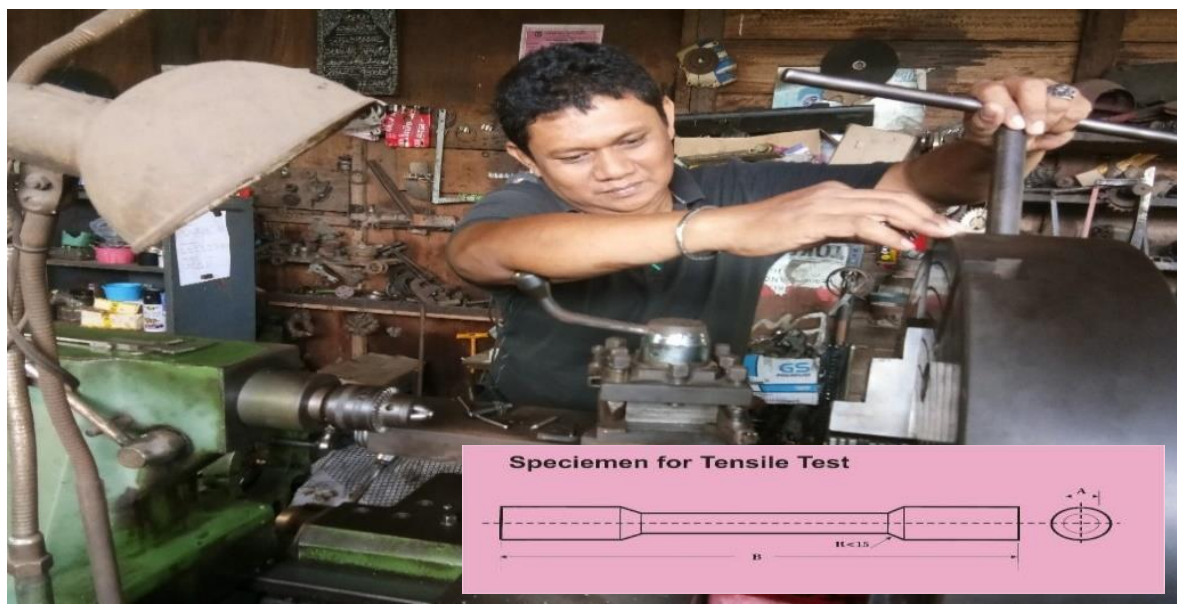

Gambar 3. Proses Pembuatan Material Uji Tarik

Tabel 3. Ukuran Material Uji tarik

\begin{tabular}{|c|c|c|c|c|c|c|}
\hline No. & Tipe & No. Mat. & $\mathbf{A}$ & B & Berat $(\mathbf{G})$ & KET. \\
\hline \multicolumn{7}{|c|}{ Material Uji Control } \\
\hline 1 & Control & A1 & 8,05 & 151,50 & 103,00 & \\
\hline 2 & Control & $\mathrm{A} 2$ & 8.05 & 149,75 & 102,00 & \\
\hline 3 & Control & A3 & 8,00 & 150,25 & 103,00 & \\
\hline \multicolumn{7}{|c|}{ Material Uji Bulan Agustus } \\
\hline 4 & Hijau & B1 & 8,00 & 150,00 & 104,00 & \\
\hline 5 & Hijau & $\mathrm{B} 2$ & 8,05 & 150,00 & 103,00 & \\
\hline 6 & Hijau & B3 & 8,10 & 150,75 & 104,00 & \\
\hline \multicolumn{7}{|c|}{ Material Uji Bulan September } \\
\hline 7 & Biru & $\mathrm{C} 1$ & 8,10 & 150,00 & 104,00 & \\
\hline 8 & Biru & $\mathrm{C} 2$ & 8,05 & 150,50 & 104,00 & \\
\hline 9 & Biru & $\mathrm{C} 3$ & 8,00 & 150,30 & 104,00 & \\
\hline \multicolumn{7}{|c|}{ Material Uji Bulan Oktober } \\
\hline 10 & Coklat & D1 & 8,1 & 150,00 & 104,00 & \\
\hline 11 & Coklat & D2 & 8,05 & 150,50 & 103,00 & \\
\hline 12 & Coklat & D3 & 8,05 & 150,10 & 102,00 & \\
\hline
\end{tabular}



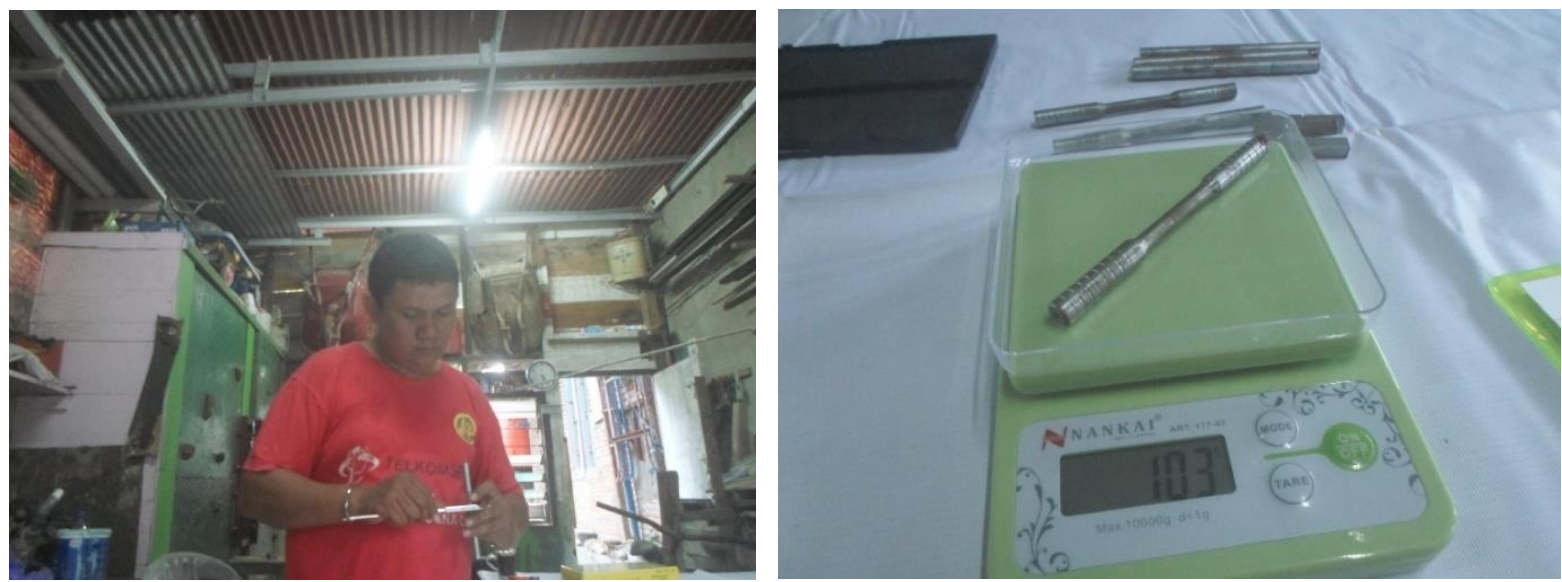

Gambar 4. Pengukuran Ulang Dimensi dan berat Material Uji
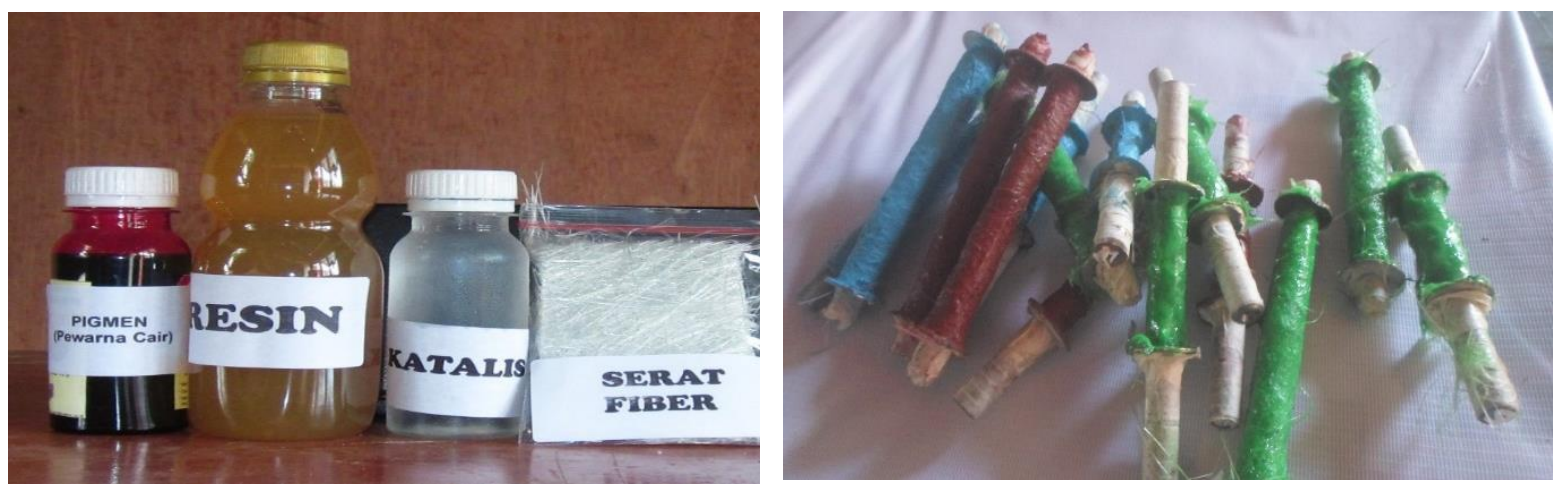

Gambar 5. Material Fiberglass dan Material terselimuti Fiberglass

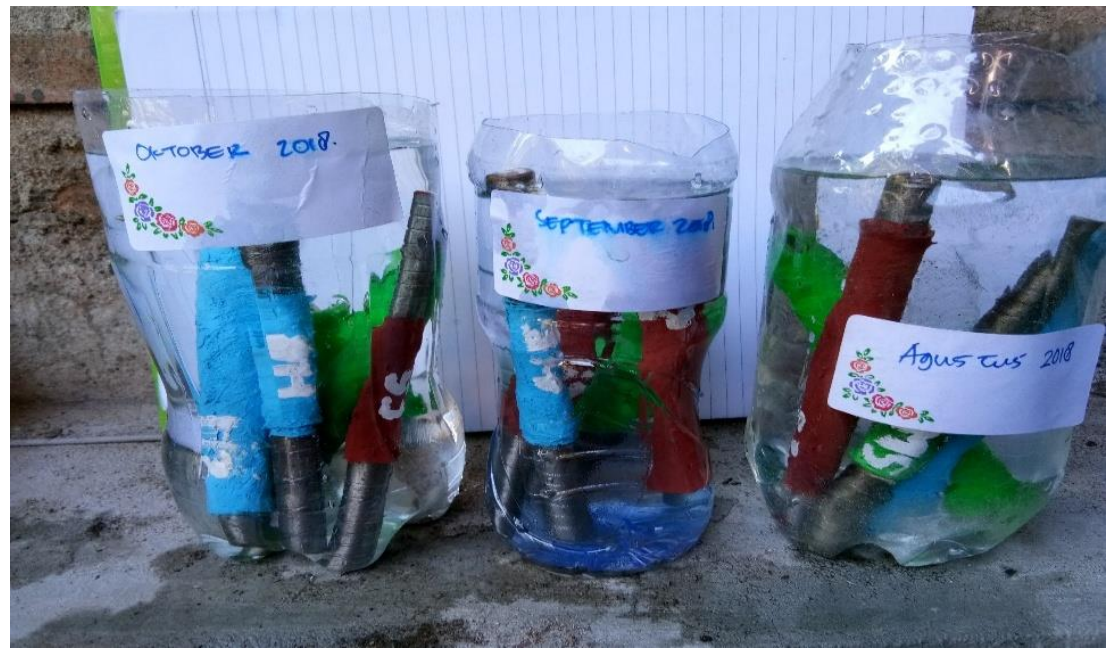

Gambar 6. Perendaman Material di dalam Wadah yang Telah Diisi Sebelumnya dengan Air Laut

\section{Pengujian Material}

Dalam melakukan pengujian tekan ini dilakukan di Laboratorium Uji laboratorium Uji Material Akademi Teknik Industri Makassar pada tanggal 14 Juli 2018 Pukul 10.30 wita. Dengan data awal sebagai berikut: 


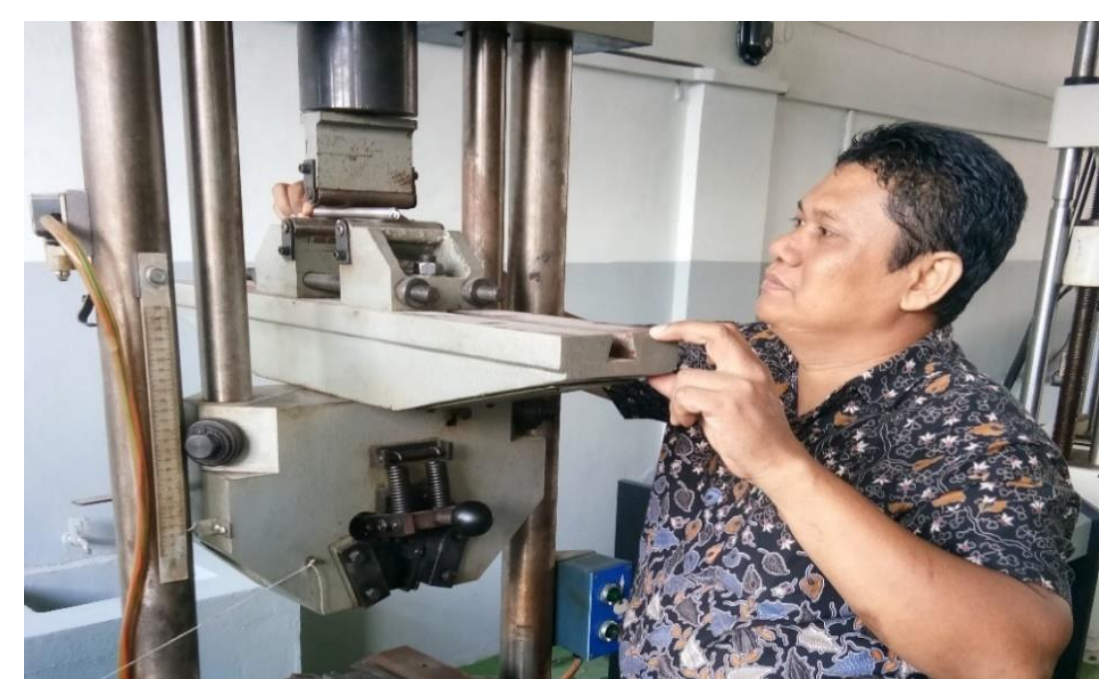

Gambar 7. Pengujian Material di Laboratorium

Tabel 4. Pengujian di laboratorium uji tarik data uji tarik sebagai berikut: Pengujian tanggal 14 Juli 2018. Pukul 10.30 Wita

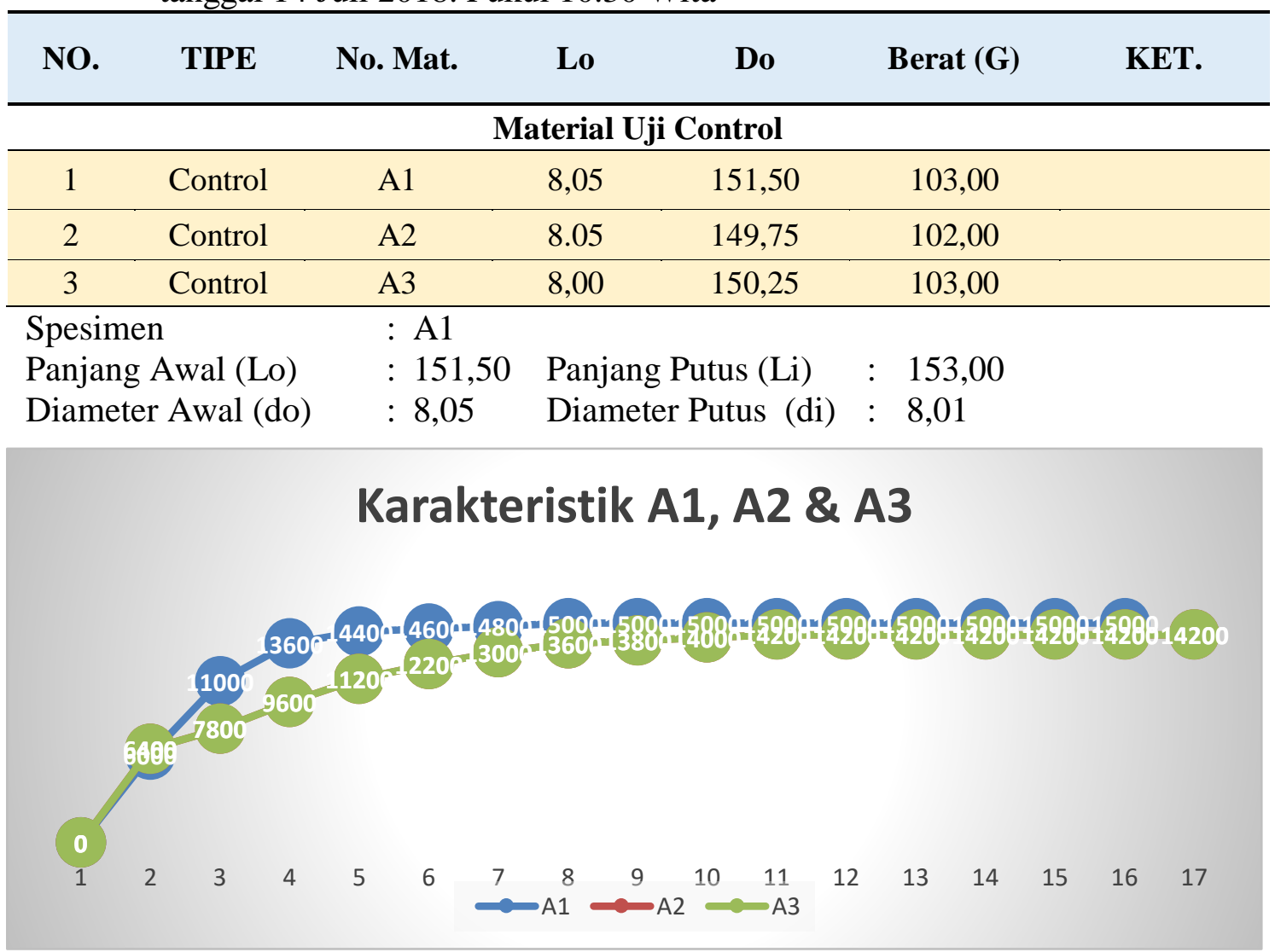

Gambar 8. Karakteristik Material

Pengujian material tahap kedua tanggal 15 Agustus 2018 Pukul 14.00 Wita. Pengujian material tahap ketiga tanggal 12 September 2018 Pukul 14.00 Wita. Pengujian material tahap ketiga tanggal 15 Oktober 2018 Pukul 14.00 Wita. 
Tabel 5. Hasil Penelitian

\begin{tabular}{|c|c|c|c|c|c|c|c|c|c|c|c|c|c|c|c|c|c|c|c|}
\hline No. & TIPE & NO. MAT. & Do & Lo & $\mathrm{pp}$ & BERAT (G) & 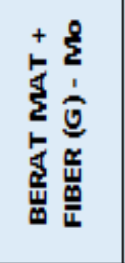 & 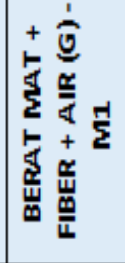 & L1 & D1 & $\begin{array}{l}\text { Beban } \\
\text { Maksimal } \\
\text { (KN) }\end{array}$ & $\begin{array}{c}\text { Beban Maksimal } \\
\text { (Kg) } \\
101,97\end{array}$ & $\begin{array}{l}\vdots \\
2 \\
0 \\
0 \\
11 \\
0\end{array}$ & $\sigma=\frac{P}{A_{0}}$ & $\begin{array}{l}\vdots \\
\Sigma \\
1 \\
\Sigma \\
11 \\
\Sigma\end{array}$ & $\begin{array}{c}9 \\
1 \\
1 \\
3 \\
3 \\
0 \\
0\end{array}$ & $E=\frac{\sigma}{e}$ & $\begin{array}{c}\text { है। } \\
\text { है। } \\
\| \\
\text { जे }\end{array}$ & KET. \\
\hline \multicolumn{20}{|c|}{ Material Uji Control } \\
\hline 1 & Control & $\mathrm{A} 1$ & 8,05 & 151,50 & 50,00 & 103,00 & & & 153,450 & 6,100 & $15.000,000$ & $1.529 .550,000$ & 402,500 & 50,669 & & 0,013 & $3.936,601$ & $3.800,124$ & \\
\hline 2 & Control & A2 & 8,05 & 149,75 & 48,50 & 102,00 & & & 151,950 & 6,200 & $15.000,000$ & $1.529 .550,000$ & 390,425 & 52,236 & & 0,015 & $3.555,623$ & $3.917,654$ & \\
\hline 3 & Control & $\mathrm{A} 3$ & 8,00 & 150,25 & 49,50 & 103,00 & & & 152,450 & 5,900 & $14.200,000$ & $1.447 .974,000$ & 396,000 & 51,501 & & 0,015 & $3.517,271$ & $3.656,500$ & \\
\hline & RATA - $R$ & RATA & 8,03 & 150,50 & 49,33 & 102,67 & & & 152,617 & 6,067 & $14.733,333$ & $1.502 .358,000$ & 396,308 & 51,469 & - & 0,014 & $3.669,832$ & $3.791,426$ & \\
\hline \multicolumn{20}{|c|}{ Material Uji Bulan Agustus 2018} \\
\hline 4 & Hijau & $B 1$ & 8,00 & 150,00 & 50,10 & 104,00 & 119,00 & 121,00 & 151,600 & 6,100 & $15.600,000$ & $1.590 .732,000$ & 400,800 & 50,884 & 2,000 & 0,011 & $4.770,378$ & $3.968,892$ & \\
\hline 5 & Hijau & $B 2$ & 8,05 & 150,00 & 50,00 & 103,00 & 120,00 & 123,00 & 152,000 & 6,200 & $15.400,000$ & $1.570 .338,000$ & 402,500 & 50,669 & 3,000 & 0,013 & $3.800,184$ & $3.901,461$ & \\
\hline 6 & Hijau & B3 & 8,10 & 150,75 & 49,50 & 104,00 & 118,00 & 120,00 & 152,950 & 6,000 & $16.200,000$ & $1.651 .914,000$ & 400,950 & 50,865 & 2,000 & 0,015 & $3.485,408$ & $4.120,000$ & \\
\hline & RATA - $\mathrm{R}$ & RATA & 8,05 & 150,25 & 49,87 & 103,67 & 119,000 & 121,333 & 152,183 & 6,100 & $15.733,333$ & $1.604 .328,000$ & 401,417 & 50,806 & 2,333 & 0,013 & $4.018,657$ & $3.996,784$ & \\
\hline \multicolumn{20}{|c|}{ Material Uji Bulan September 2018} \\
\hline 7 & Biru & $\mathrm{C} 1$ & 8,10 & 150,00 & 49,50 & 104,00 & 120,00 & 124,00 & 151,300 & 6,000 & $15.800,000$ & $1.611 .126,000$ & 400,950 & 50,865 & 4,000 & 0,009 & $5.869,038$ & $4.018,272$ & \\
\hline 8 & Biru & $\mathrm{C} 2$ & 8,05 & 150,50 & 50,00 & 104,00 & 118,00 & 121,00 & 151,950 & 6,000 & $14.400,000$ & $1.468 .368,000$ & 402,500 & 50,669 & 3,000 & 0,010 & $5.259,105$ & $3.648,119$ & \\
\hline 9 & Biru & $\mathrm{C} 3$ & 8,00 & 150,30 & 50,00 & 104,00 & 119,00 & 122,00 & 151,450 & 5,900 & $14.600,000$ & $1.488 .762,000$ & 400,000 & 50,986 & 3,000 & 0,008 & $6.663,622$ & $3.721,905$ & \\
\hline & RATA - $R$ & RATA & 8,05 & 150,27 & 49,83 & 104,00 & 119,000 & 122,333 & 151,567 & 5,967 & $14.933,333$ & $1.522 .752,000$ & 401,150 & 50,840 & 3,333 & 0,009 & $5.930,588$ & $3.796,099$ & \\
\hline \multicolumn{20}{|c|}{ Material Uji Bulan Oktober 2018} \\
\hline 10 & Coklat & $\mathrm{D} 1$ & 8,1 & 150,00 & 48,90 & 104,00 & 117,00 & 122,00 & 151,100 & 6,100 & $14.400,000$ & $1.468 .368,000$ & 396,090 & 51,489 & 5,000 & 0,007 & $7.021,242$ & $3.707,157$ & \\
\hline 11 & Coklat & $\mathrm{D} 2$ & 8,05 & 150,50 & 49,00 & 103,00 & 119,00 & 124,00 & 151,450 & 6,200 & $14.200,000$ & $1.447 .974,000$ & 394,450 & 51,703 & 5,000 & 0,006 & $8.190,872$ & $3.670,868$ & \\
\hline 12 & Coklat & D3 & 8,05 & 150,10 & 50,00 & 102,00 & 121,00 & 127,00 & 151,350 & 5,800 & $14.400,000$ & $1.468 .368,000$ & 402,500 & 50,669 & 6,000 & 0,008 & $6.084,348$ & $3.648,119$ & \\
\hline \multicolumn{3}{|c|}{ RATA - RATA } & 8,07 & 150,20 & 49,30 & 103,00 & 119,000 & 124,333 & 151,300 & 6,033 & $14.333,333$ & $1.461 .570,000$ & 397,680 & 51,287 & 5,333 & 0,007 & $7.098,821$ & $3.675,382$ & \\
\hline
\end{tabular}




\section{Hasil}

Percobaan yang dilakukan adalah pengujian tarik pada suatu material, untuk dapat mengetahui fenomena pada saat pengujian tarik dan dapat mengetahui bagaimana cara untuk mengukur keelastisan suatu material yang di beri gaya tarik. Spesimen yang digunakan sebaiknya yang memiliki grip pada kedua sisinya, agar tidak terjadi slip atau tergelincir ketika ditarik. Spesimen ini berbentuk penampang lingkaran. Pertamatama, alat uji tarik dikalibrasikan terlebih dahulu. Kemudian, spesimen ditempatkan pada penjepit yang ada di bagian atas dan bagian bawah alat uji. Namun alat yang digunakan untuk memberikan gaya tarik pada spesimen, pemutar pengendali kecepatan pada control panel sedang rusak, jadi kami hanya bisa menyaksikan bagaimana spesimen tersebut ditarik dan putus tanpa mengetahui bagaimana grafik uji tarik tersebut terpampang di monitor. Grafik tegangan-regangan pada uji tarik sangat mempengaruhi sifat material spesimen uji tarik. Semakin panjang garis grafik dengan besar tegangan yang kecil maka benda dapat digolongkan ke dalam material yang memiliki elastisitas yang tinggi. Sedangkan bila semakin pendek garis grafiknya maka dapat digolongkan dalam material yang getas.

Dalam pengujian ini ada beberapa hal yang di perhatikan tegangan, regangan, elastisitas, kuat tarik dan daya serap material fiberglas untuk mengetahui tingkat korotifitasnya. Tegangan yang terjadi pada spesimen semakin lama semakin besar seiring dengan bertambahnya perpanjangannnya. Ini mengakibatkan gaya tarik F yang bekerja pada spesimen tersebut semakin lama semakin besar. Karena adanya persamaan $\sigma=\mathrm{F} / \mathrm{A}$ di mana, $\sigma$ adalah besarnya tegangan, $\mathrm{F}$ adalah besarnya gaya yang bekerja, dan A adalah luas penampang spesimen uji coba.

Jenis material dan suhu suatu material sangat mempengaruhi ketahanan uji tarik material. Bila suatu material memiliki kegetasan yang nilainya besar, material tersebut akan mudah untuk terputus. Karena, material tersebut tidak sempat memanjang pada saat gaya tarik berlangsung, melainkan langsung putus dan menghasilkan bentuk patahan yang tidak mengerucut. Suhu material juga mempengaruhi hasil pengamatan. Semakin dingin suatu material, maka semakin getas material tersebut yang menyebabkan material menjadi tidak elastis dan mudah putus pada saat ditarik. Karena, pada saat dingin susunan atom material menjadi sangat rapat dan sulit untuk terpisah.

Umumnya pengujian tarik digunakan untuk mengetahui sifat mekanis dari suatu material terhadap tarikan. Sifat - sifat mekanis tersebut antara lain adalah keelastisitasan material. Sifat keelastisitasan material sangat penting dalam hal merancang suatu komponen atau alat, karena apabila terjadi kesalahan dalam perancangan suatu alat, maka dapat berakibat fatal, dan memahayakan. Maka dari itu pengujian tarik sangat diperlukan.

Dari hasil tabel hasil pengujian (Lampiran), didapatkan panjang diameter berubah seiring dengan bertambah panjangnya spesimen. Diameter material uji A (Kontrol) rata - rata sebelum pengujian sebesar $8,03 \mathrm{~mm}$ dan rata - rata sesudah pengujian panjang berubah manjadi $6,06 \mathrm{~mm}$. Diameter material uji $\mathrm{B}$ rata - rata sebelum pengujian sebesar $8,05 \mathrm{~mm}$ dan rata - rata sesudah pengujian panjang berubah manjadi $6,10 \mathrm{~mm}$. Diameter material uji $\mathrm{C}$ rata - rata sebelum pengujian sebesar 8,05 $\mathrm{mm}$ dan rata - rata sesudah pengujian panjang berubah manjadi $5,96 \mathrm{~mm}$. Diameter material uji D rata - rata sebelum pengujian sebesar $8,07 \mathrm{~mm}$ dan rata - rata sesudah pengujian panjang berubah manjadi $6,03 \mathrm{~mm}$. 
Tegangan $(\sigma)$ material uji A (Kontrol) rata - rata tegangan yang terjadi pada saat pengujian mencapai $51,469 \mathrm{KN} / \mathrm{mm}^{2}$. Material Uji B rata - rata tegangan yang terjadi pada saat pengujian mencapai $50,806 \mathrm{KN} / \mathrm{mm}^{2}$. Material Uji C rata - rata tegangan yang terjadi pada saat pengjian mencapai $50,840 \mathrm{KN} / \mathrm{mm}^{2}$. Sedangkan Material Uji D rata - rata tegangan yang terjadi pada saat pengujian mencapai $52,287 \mathrm{KN} / \mathrm{mm}^{2}$. Nilai perubahan tegangan tidak signifikan karena pengujian material berdasarkan perbandingan antara beban yang diberikan $(\mathrm{P})$ dengan luas penampaung material (diameter X penampang).

Regangan (e) material uji A (Kontrol) rata - rata regangan yang terjadi pada pengujian mencapai 0,014, material uji B rata - rata regangan yang terjadi pada pengujian mencapai 0,013 , material uji $\mathrm{C}$ rata - rata regangan yang terjadi pada pengujian mencapai 0,009 , material uji $\mathrm{D}$ rata - rata regangan yang terjadi pada pengujian mencapai 0,007 . Pada pengujian regangan terjadi perubahan yang signifikan hal ini dipengaruhi, adanya material baru yang masuk kedalam bahan uji sehingga regangan material tersebut regangannya berubah dari waktu kewaktu.

Modulus Elastisitas (E) material uji A (Kontrol) rata - rata Modulus Elastis yang terjadi pada pengujian mencapai 3.669,83, material uji B rata - rata Modulus Elastis yang terjadi pada pengujian mencapai 4.018,657, material uji $\mathrm{C}$ rata - rata Modulus Elastis yang terjadi pada pengujian mencapai 5.930,588, material uji D rata - rata Modulus Elastis yang terjadi pada pengujian mencapai 7.089,821. Pada pengujian Modulus Elastis terjadi perubahan yang signifika月 (bertambah besar niali rata ratanya) berarti bahan uji semakin sulit untuk direntangkan dalam artian membutuhkan gaya yang lebih besar. Hal ini di pengaruhi karena fiberglass mengikat material dengan kuat sehingga material bertambah sulit untuk direntangkan.

Kuat Tarik (Su) dan berat setelah perendaman material uji A (Kontrol - Material didak direndam) rata - rata Kuat Tarik mencapai 3.791,426 KN/mm². Material uji B rata - rata Kuat Tarik mencapai $3.996,784 \mathrm{KN} / \mathrm{mm}^{2}$. Berat $119 \mathrm{~g}$ setelah perendaman 121,333. Material uji C rata - rata Kuat Tarik mencapai 3.796,099 KN/mm². Berat 119 g setelah perendaman 122,333 Dan Material uji D rata - rata Kuat Tarik mencapai $3.675,382 \mathrm{KN} / \mathrm{mm}^{2}$. Berat $119 \mathrm{~g}$ setelah perendaman 124,333. Dari hasil uji diatas dapat dilihat dalam perendaman selama satu bulan uji tarik uji tarik meningkat dan masuk pada bulan kedua dan ketiga pengujian kuat tarik menurun, diakibatkan terjadinya korosi pada material.

\section{KESIMPULAN}

Dari percobaan yang telah dilakukan, dapat disimpulkan bahwa :

a) Nilai perubahan tegangan tidak signifikan karena pengujian material berdasarkan perbandingan antara beban yang diberikan $(\mathrm{P})$ dengan luas penampaung material.

b) Pada pengujian regangan terjadi perubahan yang signifikan hal ini dipengaruhi, adanya material baru yang masuk ke dalam bahan uji sehingga regangan material tersebut regangannya berubah dari waktu kewaktu.

c) Pada pengujian Modulus Elastis terjadi perubahan yang signifikan (bertambah besar niali rata - ratanya) berarti bahan uji semakin sulit untuk direntangkan dalam artian membutuhkan gaya yang lebih besar. Hal ini di pengaruhi karena fiberglass mengikat material dengan kuat sehingga material bertambah sulit untuk direntangkan. 
d) Dari hasil uji diatas dapat dilihat dalam perendaman selama satu bulan uji tarik uji tarik meningkat dan masuk pada bulan kedua dan ketiga pengujian kuat tarik menurun, diakibatkan terjadinya korosi pada material.

\section{DAFTAR PUSTAKA}

D.L. Sanggarang. (2004). Membuat Kerajinan Berbahan Fiberglass. Jakarta: Kawan Pustaka :

G. Takeshi Sato dan N. Sugiarto H. (1983). Menggambar Menurut Standar I. S. O. Jakarta: Pradnya Pratama

Gupta, V.B. and V.K. Kothari . (1997). Manufactured Fibre Technology. London: Chapman and Hall.

Kyung-Jun Chu.(1998). Eur. Polym. J. Vol. 34, No. 3/4, pp. 577-580

Loewenstein, K.L. (1973). The Manufacturing Technology of Continuous Glass Fibers. New York: Elsevier Scientific.

Lubin, George.1975. Handbook of Fiberglass and Advanced Plastic Composites. Huntingdon NY: Robert E. Krieger..

Mohr, J. G. and W. P. Rowe.(1978). Fiberglass. Atlanta: Van Nostrand Reindhold.

Novizal. (2012). Pelapisan Ni-Co Pada Baja ST 37 menggunakan metode elektroplating dengan perlakuan panas, ISSN : 2089-3582 Vol 3, No. 1

R. Kleinschmidt et al. (2000). Journal of Molecular Catalysis A: Chemical, 157, 8390

Simatupang, E.R. (2008). Korosi "Perusak yang Terabaikan", Teknik Mesin. Universitas Bung Hatta

SNI No. 07 - 0410 - 1989 Uji Tekan Baja. Dewan Standarisasi Indonesia

SNI No. 07- 2529 - 1991 Uji Tarik Baja. Dewan Standarisasi Indonesia

SNI No. 07 - 0552 - 1989 Uji Puntir Baja. Dewan Standarisasi Indonesia

Song et al. (2004). Macromol. Symp. 213, 173-185

Sugiyono. (2008) Metode penelitian Administrasi . Bandung: Alpabeta.

Tata Surdia (2000). Pengetahuan Bahan Teknik. Jakarta: Pradnya Paramita.

Volf, Milos B.(1990).Technical Approach to Glass. New York: Elsevier. 
PENA TEKNIK: Jurnal Ilmiah Ilmu-Ilmu Teknik

Volume 4, Nomor 1, Maret 2019: 35 - 45

Halaman ini sengaja dikosongkan 